illustrating the different senses of the English words are omitted as unnecessary. Should the work be carried out on these lines it will enable the student to wait somewhat more patiently for the appearance of $\mathrm{Mr}$. Whitmee's long-promised Comparative Dictionary of the Polynesian Languages.

THE Minister for Postal Telegraphy will ask from the French Parliament the credits required for connecting by a cable Saigon to Haifong, the principal seaport of Tonquin, and Haifong to Hanoi by another line laid down in the bed of the Red River.

AT the Polytechnic, which is now occupied by a Young Men's Christian Institute, there was recently an exhibition of drawings, and works of art and manufactures, executed wholly or in part by the members of the institute and the students at the numerous classes held there. Most of the exhibits show proofs of the usefulness and success of the institution. The exhibition included also many valuable works of art and a very costly and interest. ing collection of Japanese, Chinese, and Indian curiosities lent for the occasion by Mr. Quintin Hogg and other friends of the institute.

THE Oxford University Junior Scientific Club held a very successful conversazione in the University Museum on Friday evening last.

Prof. Dewar, F.R.S., will give an experimental discourse on the Chewistry of the Electric Discharge at the last Friday evening meeting on June 8 at the Royal Institution.

THE additions to the Zoological Society's Gardens during the past week include two Pig-tailed Monkeys (Macacus nemestrinus o $q$ ) from Sarawak, presented by His Highness the Rajah of Sarawak; an Egyptian Cat (Felis chaus) from India, presented by Mr. W. R. Glyn Griffiths; three Common Kingfisbers (Alcedo ispida), Britisb, presented by Mr. Frederic Houghton; a Barbary Ape (Macacus inuus) from North Africa, four Elliot's Pheasants (Phasianus ellioti of $\delta$ \& $\&$ ) from China, five Ceylon Terrapins (Clemmys trijuga) from Ceylon, four Bungoma River Turtle (Emyda granosa) from India, four Lacertine Snakes (Colopeltis lacertina), a Horseshoe Snake (Zamenis hippocrepis), a Pleurodele Newt (Pleurodeles revalti), South European, a Red-legged Partridge (Caccabis rufa), European, deposited; a Buffon's Touracou (Corythaix buffoni) from West Africa, two Bronze-winged Farrots (Pionus chalcopterus) from South America, two Varied Hemipodes (Turnix varia) from Australia, two American Siskins (Chry'somitris tristis) from North America, two Black Larks (Melanocorypha yellonensis) from Siberia, a Cerastes Viper (Vipera cerastes) from Egypt, purchased.

\section{LOCAL SCIENTIFIC SOCIETIES}

$\mathrm{F} O \mathrm{R}$ some years past there has been a growing expression of desire of local scientific societies to be officially represented at the meetings of the British Association. The question is one of considerable difficulty and delicacy, and though it has been the subject of frequent discussion and some legislation, no measure has yet been carried that is satisfactory to all parties. Last year the subject was referred to the Council, who appointed a special committee, and this committee made on Tuesday its preliminary report. They asked in it for permission from the Council to circulate the report among the local societies in order to obtain from them that response which is needed before the committee can feel themselves in a position to report finally, and a fortiori before the Council can take their report into consideration. This permission bas been granted, together with that of free publication. A copy of the report will consequently be shortly sent to the various societies by the secretary, Mr. H. George Fordham, Odsey Grange, Rnyston, Cambridgeshire, with the request that their replies will be forwarded to him. But as the subject presses, and as the season is advancing and the annual sessions of societies are drawing to a close, the best method of bringing the report before the members of those societies is through the columns of NATURE. I therefore forward it at once.

FRANCIS GALTON June 6

Preliminary Report of the "Local Scientific Societies" Committee, consisting of Mr. FRANCIS GALTON (Chairman), the Rev. Dr. Crosskey, Mr. C. E. De Rance, Mr. H. G. FORdham (Secretary), Mr. JOHN HOPKInson, Mr. R. Meldola, Mr. A. Ramsay, Prof. Sollas, Mr. G. J. Symons, and Mr. W. WhITAKER, appointed by the Council in compliance with the following resolution referred to the Council by the General Committee:

"That the Council be empowered to appoint a Committee, as recommended in their Report adopted by the General Com. mittee on August 23, in order to draw up suggestions upon methods of more systematic observation and plans of operation for Local Societies, together with a more uniform mode of publication of the re-ults of their work. It is recommended that this Committee should draw up a list of Local Societies which publish their proceedings."

The Committee have communicated with all the Societie: known to them which appear to fall under the designation of "Local Societies which publish their proceeding ", giving to this definition a somewhat liberal interpretation, and they :ubmit a tabular list of the publications with other particulars of those which have furnished replies. These societies are about I70 in number, and seem from their rules and publinations to be centres whence local scientific information may conveniently be obtained.

The Local Societies differ widely in character. Those which are established in large towns, and are not particularly well situated for carrying on systematic local investigations, are often of high scientific rank, and their affairs are administered in a business-like manner by a regular staff. On the other hand, there are numerous smaller societies and field clubs, scattered over the country, which are excellently placed for conducting local investigations, but whose organisation is so incomplete that it has often been difficult to discover their official arldresses.

In some parts of the country the smiller societies either group themselves into what is practically a federation, or else affiliate themselves to some large society in their district, and the Committee think that if the Local Societies generally could be induced to group themselves round what might be described as local subcentres, it would not be difficult to devise methods of uniting the representatives of those sub-centres in the rerformance of interesting and important duties during the meetings of the British Association, with the final effect of establi-hing systematic local investigation throughout the country, and uniformity in the modes of publishing the results. The recommendations the Committee are about to make will tend wholly in this direction, because, although they have considered many plans of fulfilling their instructior $s$ in a direct manner that perhaps look well on paper, no plan rcommends itself to them as superior to this indirect method in its capacity of producing valuable and durable effects.

The Committee do not suggest any new topics for systematic investigation, but confine themselves to giving a few examples of what these topics are, taken from a circular printed last year by a committee appointed at a conference of delegates of scientific societies : (1) Underground Waters (to record the height of water in wells, and its variations in level in different parts of the country). (2) Erratic Blocks (to record their position, height above sea, lithol gical character, \&c.). (3) Underground Temperature (to investigate the rate of its increa:e downwards in various localities). (4) Rainfall (its measurement). (5) Periodical Natural Phenomena (to record time of flowering of certain plants, arrival of certain migratory birds, appearance of certain insects). (6) Injurious Insects (to record their appearance in unusual numbers, the injuries they cause, and the degrees of success in preventing them). The first three of these investigations were set on foot by Committees of the British Association, and the last three by societies or private individuals.

It can hardly be doubted that numerous systematic investigations of a local character will from time to time be carried on, and that their successful prosecution would result in important gains to science. Neither does it appear doubtful 
that the successful prosecution of such investigations by the smaller Local Societies would be greatly encouraged and facilitated by the general interest shown in their work by the more influential societies in their neighbourhood, by a watchful oversight, a readiness to discuss and publish results, and by the personal influence of their leading members. The Committee offer tre recommendations they are about to make in the tru: $t$ that, if the Council are pleased to publish them, they will serve to remind the more important Local Societies of the high and useful function they are able to perform by entering into friendly and helpful relations with the small and scattered societies of their respective-districts, and by offering themselves as their scientific representatives wherever representation may be necessary.

The Committee recommend that they be empowered to print and circulate among the Local Societies the following draft of suggested rules, to give an opportunity to those societies of taking that initiative without which no action on the part of the Association is likely to produce much effect. After the Committee have been informed of the views of these societies, they will be in a better position than they are at the present moment for appreciating at its true value the desire for cooperation which they believe to exist. They will also perhaps receive useful suggestions from the societies that have not occurred to themselves, and they will probably be in a position to submit their final recommendations before the approaching annual meeting.

"Suggested New Rules, the Existing Rules being ALTERED ACCORDINGLY.

"Corresponding Local Societies.

"Application may be made by any society publishing scientific memoirs to be placed on the list of Corresponding Local Societies of the British Association. These applications must be addressed to the Secretary, and be made on or before the second day of the annual meeting, and they must be accompanied with a copy of the publications of the Society during the preceding year.

"The Secretary shall transmit the e applications to a Committee appointed by the Council for the purpose of con-idering them, as well as for that of keeping themselves generally informed of the annual work of the Corresponding Local Societies. This Committee shall make an annual report to the Committee of Recommendations, and shall suggest such additions or changes in the list as they may think desirable; but the final determination of the list will rest with the Committee of Recommendations, subject only to the conditions-(I) That the number of Societies on the list shall not exceed that which is prescribed by the Council ; (2) that the intended removal of any Society from the list shall not take effect until immediately before the commencement of the next annual meeting.

"The privileges of a Corresponding Local Society shall consist in-(a) The insertion in the Annual Report of the British Association of an index, in such abbreviated form as the Counci may sanction, of the titles of the scientific memoirs published by the Society during the previous year; $(b)$ the right to nominate any one of its members, who is also a member of the British Association, as its delegate to the annual meeting of the Association, who shall have for the time the rights of a member of the General Committee.

"Before the delegate can enter into his rights, he must trans. mit to the Secretary of the British Association a copy of the publications during the previous year of the Society he represents. He must also fill up a schedule, that will be furnished to him by the Secretary on application. This schedule wi'l ask for- $-(a)$ The names of the President and chief executive officer of his Society; $(b)$ a list of the institutions, if any, in its neighbourhood with which it bas official relations and whose interests it represents ; $(c)$ a brief report on the character, number, and results of any systematic local observations carried on during the past year, either by itself or by any of the institutions on the foregoing list: (I) at the instance of Committees of the British Association, (2) at the instance of other Societies or private persons; $(d)$ such other information as may be thought desirable.

"The delegates of the various Corresponding Local Societies shall constitute a Committee, which shall be summoned by the Secretary of the Association to hold one or more meetings during each annual meeting of the Association, under a Chairman and with a Secietary appointed by the Council. The Secretaries of each Section shall be instructed to transmit to the
Secretary of the Committee of Delegates copies of any recom. mendations forwarded by the Pre:idents of Sections to the Committee of Recommendations bearing upon matters in which the cooperation of Local Societies is desired; and the Secretary to the Committee of Delegates shall invite the authors of those recommendations to attend the meefing of the Committee an $t$ give verbal explanations of their objects and of the precise way in which they would desire to have them carried into effect, and to discuss difficulties that may be raised by any member of the Committee, so that the Delegates may be qualified on their return to bring those recommendations clearly and favourably before the notice of their respective Societies."

The Committee believe that the distinction accorded to a Local Society through its selection and formal recognition by the British Association as one of its Corresponding Societies, the advantage of a widely-circulated notice of its work in so important a volume as the Report of the British Association, and the honourable and useful duties as:igned to its delegate, would give considerable value to the title.

They also anticipate that a Local Society, which had asked for and received recognition as the representative centre for the time being of the institutions in its district, would be thereby stimulated to exercise that very creditable and important function with increased zeal and efficiency. The result would be to strengthen the mutual relations of the larger and the smaller Local Societies, to insure the encouragement of any disposition to engage in systematic investigations, and to establish a practice of printing the scattered results obtained by the smaller Local Societies of any district in a consolidated form in the publications of their leading Society.

Finally, the Committee believe that the annual meetings of the proposed Committee of Delegates, under the chairmanship of a distinguished member of the Association, would have large influence in harmonising the action of their several Societies, and that it would offer a facility that does not now exist for the natural and healthy growth of a federation between remote Societies which have no more direct bond of union than througl the British A:scciation.

\section{THE ROYAL OBSERVATORY}

$T H E$ following are the leading points referred to in the Report of the Astronomer Royal to the Board of Visitors of the Royal Observatory, Greenwich, read at the annual visitation on June 2.

On the subject of Astronomical Observations Mr. Christie says :- -

"The regular subjects of observation are the sun, moon, planets, and fundamental stars, with other stars from a selected list. The working catalogue of 2500 stars down to the fifth magnitude having been cleared off, a new working list of 2600 stars, comprising all stars down to the sixth magnitude inclusive which had not been observed since 1860 , has been prepared, and was brought into use at the beginning of March. About 1200 stars were observed in $I \delta 82$, but amongst these there are nearly 5co single observations, necessitating careful comparison with catalogue place for the detection of any mistakes of observation or reduction. The labour thus entailed is considerable, and efforts will be made to obtain in this and each future year at least two observations of every star observed.

"The following statement shows the number of observations with the transit-circle made in the year ending 1883 , May 20 :Transits, the separate limbs being counted as

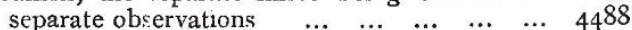

Determinations of collimation error $\quad \ldots \quad \ldots \quad \ldots \quad \ldots \quad 354$

$\begin{array}{lllllll}\text { Determinations of level error } & \ldots & \ldots & \ldots & \ldots & 323\end{array}$

$\begin{array}{llllllll}\text { Circle observations } & \ldots & \ldots & \ldots & \ldots & \ldots & \ldots & 4485\end{array}$

Determinations of nadir point (included in the

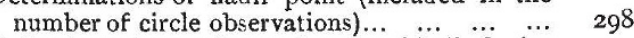

Reflection observations of stars (similarly included)

"Comet $a$ I 882 bas $\dddot{b}$ been observed seven times on the meridian since the date of the last Report, and Comet $b 1882$ has been observed three times.

"As regards the computations-

Clock times of transit over the true meridian after all corrections for instrumental errors

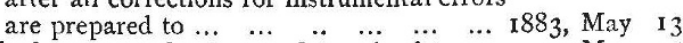

Clock errors and rates are determined to ... May 5

Mean R.A.'s on 1883 , January I, are formed

$$
\begin{array}{llllllllll}
\text { to } \ldots & \ldots & \ldots & \ldots & \ldots & \ldots & \ldots & \ldots & \ldots & \text { April } 25
\end{array}
$$

